\title{
Impact of Different Methods of Soil Sampling and DNA Extraction on the Identification of Soil Bacterial Abundance under Elevated $\mathrm{CO}_{2}$
}

\author{
Fengxia Li1,2, Saman Bowatte1, Paul C. D. Newton'1, Dongwen Luo ${ }^{1}$ \\ ${ }^{1}$ Agresearch Grasslands, Palmerston North, New Zealand \\ ${ }^{2}$ Agriculture Resource and Environment Institute of Ningxia Academy of Agriculture and Forestry Science, Yinchuan, China \\ Email: lifengxia1211@sina.com
}

How to cite this paper: Li, F.X., Bowatte, S., Newton, P.C.D. and Luo, D.W. (2017) Impact of Different Methods of Soil Sampling and DNA Extraction on the Identification of Soil Bacterial Abundance under Elevated $\mathrm{CO}_{2}$. Open Access Library Journal, 4: e3527.

https://doi.org/10.4236/oalib.1103527

Received: March 15, 2017

Accepted: November 7, 2017

Published: November 10, 2017

Copyright $\odot 2017$ by authors and Open Access Library Inc.

This work is licensed under the Creative Commons Attribution International License (CC BY 4.0).

http://creativecommons.org/licenses/by/4.0/

\begin{abstract}
Elevated atmospheric $\mathrm{CO}_{2}\left(\mathrm{eCO}_{2}\right)$ is anticipated to have marked effects on soil microbial populations. While there is experimental evidence to support this view there are also studies where changes in microbial populations, such as the abundance of bacteria, are suggested but cannot be statistically established. We conducted this study to identify whether the sampling and sample treatment methods used could influence the results obtained using bacterial abundance as the variable of interest. We tested three different sampling methods and two different DNA extraction kits. The first because microbes are distributed heterogeneously in soil so the sampling procedure might be expected to influence the accuracy and precision of the population estimate and the second because the quantity and quality of DNA extracted influences the microbial analyses that can be performed and can introduce bias. Samples were taken from a long-running FACE experiment on grassland from under plants of Agrostis capillaris. We found that bacterial abundance was consistently lower under $\mathrm{eCO}_{2}$ but we were only able to establish a statistical difference where a more intense sampling regime was used and bulking of the soil sample was avoided. A reduction in bacterial abundance is a consistent outcome in $\mathrm{eCO}_{2}$ field experiments but the only other occasion where this reduction has been found to be significant was also where individual soil cores were analysed rather than the samples being bulked. We conclude that while there is extra work and cost attached to more detailed sampling this approach is highly desirable if we are to make robust conclusions about the impacts of $\mathrm{eCO}_{2}$ on soil microbes.
\end{abstract}

\section{Subject Areas}

Agricultural Science, Soil Science 


\section{Keywords}

DNA Extraction Kit, DNA Yield, DNA Quality, Gene Abundance, Bacterial 16S rRNA, Free Air Carbon Dioxide Enrichment

\section{Introduction}

There is strong experimental evidence that soil properties are altered by elevated concentrations of atmospheric $\mathrm{CO}_{2}\left(\mathrm{eCO}_{2}\right)$ [1] [2] [3]. These changes have important consequences for agricultural production through issues such as fertiliser use [4] [5] and the nutritional composition of crops [6], for the function of natural ecosystems including biodiversity and for future concentrations of atmospheric $\mathrm{CO}_{2}$ as soils may act a source or sink for carbon (C) [7] [8]. Changes in soil properties are primarily a consequence of the activities of soil microbes [9] [10] (Schimel and Bennett 2004; Van Der Heijden et al. 2008) which are themselves responding to changes in their environment and resources resulting from plant responses to $\mathrm{eCO}_{2}$ [11] [12] [13] [14] [15]. A full understanding of the likely direction of change in soil properties and the mechanism causing these changes therefore requires an understanding of microbial population size and activity under $\mathrm{eCO}_{2}$ [16] [14].

Measuring microbial populations is difficult. Two factors that are particularly challenging are a) ensuring that the soil sampling methodology provides an accurate estimation of the population given that microbes are frequently distributed heterogeneously in soil [17] [18] [19]; and b) ensuring that the method chosen for DNA extraction is appropriate as the choice of method potentially influences the precision and accuracy of the data and thus the statistical inferences that can be drawn about the microbial populations [20] [21] [18] [19]. Table 1 shows examples where 'differences' have been observed in bacterial abundance under $\mathrm{eCO}_{2}$ but these effects have not been statistically significant. Additionally there are costs in both time and materials that may differ between sampling methods and have a bearing on the choice of protocol.

In this paper we compare methods for quantifying bacterial populations in a pasture exposed to $\mathrm{eCO}_{2}$ in a long-running Free Air Carbon Dioxide Enrichment (FACE) experiment on grassland [22]. We took soil samples from under a specific grass species-Agrostis capillaris L.; soil samples from this species have previously been shown to differ in their nitrification potential depending on the atmospheric $\mathrm{CO}_{2}$ concentration so we expected associated changes in bacterial population abundance [11]. We tested three sampling approaches and two methods of DNA extraction commonly used in $\mathrm{eCO}_{2}$ experiments [23] [24] [25] [26] [27].

\section{Materials and Methods}

\subsection{New Zealand Free Air Carbon Dioxide Enrichment Experiment (NZFACE)}

The NZFACE is situated on a mixed plant species sheep-grazed pasture near 
Table 1. Soil sampling protocol and DNA extraction kit used in field experiments with elevated $\mathrm{CO}_{2}$ and the impact of eCO bacterial abundance measured as copy number of the 16S rRNA gene and showing whether the result was significant (sig.) or non-significant (NS).

\begin{tabular}{|c|c|c|c|c|c|c|c|c|}
\hline \multirow[b]{2}{*}{ Ecosystem and $\mathrm{CO}_{2}$ enrichment system } & \multicolumn{3}{|c|}{ Sampling protocol } & \multicolumn{3}{|c|}{ DNA extraction kit } & \multirow{2}{*}{$\begin{array}{l}\text { Bacterial } \\
\text { abundance }\end{array}$} & \multirow[b]{2}{*}{ Reference } \\
\hline & $\begin{array}{l}\text { Individual } \\
\text { soil cores }\end{array}$ & $\begin{array}{c}\text { Bulked } \\
\text { soil }\end{array}$ & $\begin{array}{l}\text { Bulked } \\
\text { DNA }\end{array}$ & MoBio & Fast & $\begin{array}{l}\text { Other } \\
\text { method }\end{array}$ & & \\
\hline Planted grassland; Open top chambers & & $\sqrt{ }$ & & $\sqrt{ }$ & & & Reduced, NS & (Castro et al. 2010) \\
\hline Aspen; FACE & & & & & $\square \sqrt{ }$ & & Reduced, NS & (Dunbar et al. 2014) \\
\hline Heathland: FACE & & $\sqrt{ }$ & & & & $\sqrt{ }$ & Reduced, NS & (Haugwitz et al. 2014) \\
\hline Native grassland; mini-FACE & & $\sqrt{ }$ & & $\sqrt{ }$ & & & Reduced, NS & (Hayden et al. 2012) \\
\hline $\begin{array}{l}\text { Mixed grassland dominated by Agrostis } \\
\text { capillaris near to the } \mathrm{CO}_{2} \text { vent; } \mathrm{CO}_{2} \text { spring }\end{array}$ & $\sqrt{ }$ & & & & & $\sqrt{ }$ & Reduced, sig. & (Oppermann et al. 2010) \\
\hline This paper & $\sqrt{ }$ & & & $\sqrt{ }$ & & & Reduced, sig. & \\
\hline This paper & $\sqrt{ }$ & & & & $\sqrt{ }$ & & Reduced, sig. & \\
\hline This paper & & $\sqrt{ }$ & & $\sqrt{ }$ & & & Reduced, NS & \\
\hline This paper & & $\sqrt{ }$ & & & $\sqrt{ }$ & & Increased, NS & \\
\hline This paper & & & $\sqrt{ }$ & $\sqrt{ }$ & & & Reduced, NS & \\
\hline This paper & & & $\sqrt{ }$ & & $\square$ & & Reduced, NS & \\
\hline
\end{tabular}

Bulls $\left(40^{\circ} 14^{\prime} \mathrm{S}, 173^{\circ} 16^{\prime} \mathrm{E}\right)$ in the North Island of New Zealand. The average annual temperature at the site is $12.9^{\circ} \mathrm{C}$ and average total annual rainfall $870 \mathrm{~mm}$. The experiment consists of six rings of $12 \mathrm{~m}$ in diameter with three of these left at ambient $\mathrm{CO}_{2}\left(\mathrm{aCO}_{2}\right)$ and three enriched with $\mathrm{CO}_{2}$ during the photoperiod, with enrichment continuous throughout the year. From October 1997 until December 2011 the enrichment was to $475 \mathrm{ppm}$. The $\mathrm{CO}_{2}$ enrichment was suspended in December 2011 until July 2013 to conduct technical maintenance and then resumed with a target concentration of 500 ppm. From 1997 to 2011 the rings were grazed periodically by adult sheep under a protocol described in Newton et al (2014) [28]; thereafter (from 2013 onwards) the rings were cut with a mower and the clippings removed from the site. In October 2012 an irrigation system was installed and all the rings were irrigated to maintain pasture growth during periods of water deficit (usually December-February).

The pasture is a permanent grassland-uncultivated for at least 50 yearscontaining a mixture of $C_{3}$ and $C_{4}$ grasses, forbs and legumes [29] [28]. $C_{3}$ grasses are the most abundant group with Agrostis capillaris (browntop), a grass typically found in low-fertility situations [30], one of the dominant species under both ambient $\mathrm{CO}_{2}\left(\mathrm{aCO}_{2}\right)$ and $\mathrm{eCO}_{2}[31]$.

The soil at the site is a black loamy fine-sand (a Mollic Psammaquent). During the course of the experiment fertiliser was added-superphosphate, potassium and magnesium sulphate-to maintain soil concentrations at recommended levels [32] (Cornforth and Sinclair 1984). No nitrogen (N) fertiliser was added, the $\mathrm{N}$ inputs coming solely from biological nitrogen fixation by the legume species. 
Details of soil properties and changes over time can be found in [2].

\subsection{Soil Sampling}

In January 2014 soil samples were collected for this experiment. Patches of browntop were identified and soil was sampled from these sites. Soil cores were taken to a depth of $75 \mathrm{~mm}$ using a $25 \mathrm{~mm}$ diameter steel soil corer. There were five browntop patches in each ring and a core was taken from each patch. Three experimental protocols were then used: first (Figure 1(A)) DNA was extracted

\section{(A) Individual soil cores}

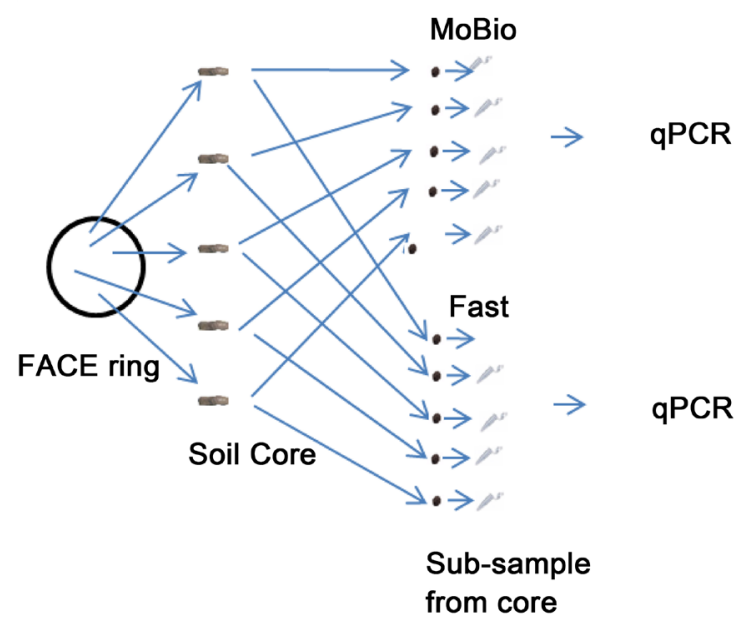

(B) Bulked soil



FACE ring

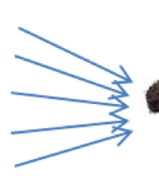

Soil Core

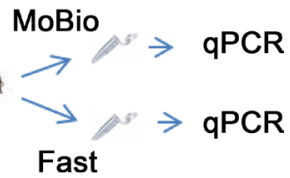

Bulked soil sample

\section{(C) Bulked DNA}

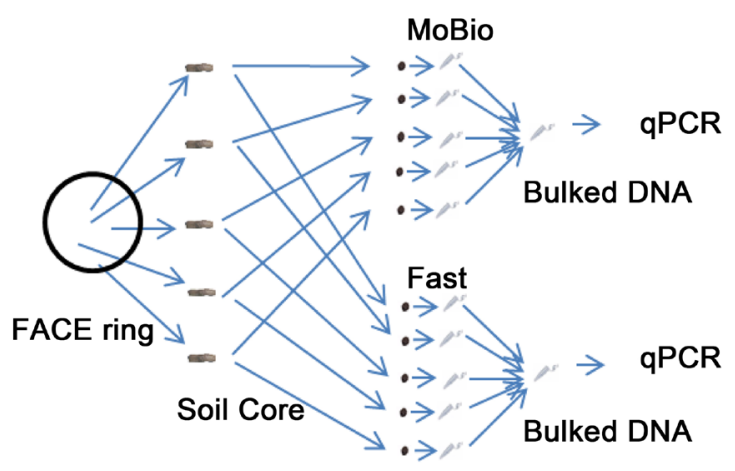

\section{Sub-sample from core}

Figure 1. Schematic to show the different experimental protocols compared in this paper. 
from each of the five cores sampled per ring and qPCR completed on all the samples; second (Figure 1(B)), the five soil cores from each ring were bulked and DNA extracted from this single sample per ring; third (Figure $1(C)$ ) as for the first protocol (A) but the DNA was bulked after extraction giving a single sample per ring for qPCR. Note that in each case $\mathrm{n}=3$ for the $\mathrm{CO}_{2}$ treatment but there were five qPCR samples per ring for method A) and one qPCR sample for (B) and (C). Importantly, the three approaches used the same soil cores thus allowing a direct comparison of the protocols and extraction kits. The soil samples were stored at $-20^{\circ} \mathrm{C}$ until DNA extraction. A sub-sample of soil was used to measure soil moisture by oven-drying at $105^{\circ} \mathrm{C}$ for $24 \mathrm{~h}$.

\subsection{DNA Extraction from the Soil and DNA Quality and Quantity Assessment}

Two DNA extraction kits were evaluated in this study, the FastDNA Spin kit for soil (MP Biomedicals, Solon, OH, USA) (hereafter described as the Fast kit) and the MoBio PowerSoil DNA isolation kit (MO BIO, Carlsbad, CA, USA) (hereafter described as the MoBio kit). All operations were conducted according to the manufactures instructions. DNA was extracted from $0.5 \mathrm{~g}$ fresh soil (approximately $0.3 \mathrm{~g}$ dry soil) for the Fast kit and $0.25 \mathrm{~g}$ fresh soil (approximately $0.15 \mathrm{~g}$ dry soil) for the MoBio kit. The quantity and quality of extracted DNA was assessed on the basis of absorbance at 260 and $280 \mathrm{~nm}$ using the NanoDrop ND-1000 (NanoDrop, Wilmington, DE, USA). An A260/A280 ratio of 1.8 - 2.0 is indicative of high purity [33] [34]. All extracted DNA was stored at $-20^{\circ} \mathrm{C}$ until required for further analysis.

\subsection{Real-Time PCR Analysis}

The abundance of the 16S rRNA gene of bacteria was quantified in triplicate by real-time PCR using a LightCyclerTM 480П (Roche, Vienna, Austria). The real time PCR reaction mixture contained $10 \mu 10 \times$ SYBR Green iCycler iQ mixture (Roche Applied Science, Germany), $0.2 \mu \mathrm{l}$ each of the primers Bacteria 968F; AACGCGAAGAACCTTAC and Bacteria 1378R; CGGTGTGTACAAGGCCCG

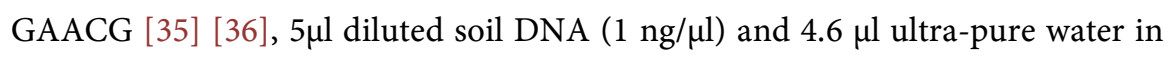
a total of $20 \mu \mathrm{l}$ reaction volume. Standard curves were obtained using serial dilutions of a known amount of plasmid DNA containing a fragment of the respective genes. The thermal cycle conditions were $95^{\circ} \mathrm{C} 10 \mathrm{~s}, 58^{\circ} \mathrm{C} 10 \mathrm{~s}, 72^{\circ} \mathrm{C} 10 \mathrm{~s}, 45$ cycles. Copy numbers of all gene targets were normalized based on grams of dry soil.

\subsection{Statistical Analysis}

The effects of atmospheric $\mathrm{CO}_{2}$, sampling protocol and DNA extraction kits were tested by a mixed effects model with heterogeneous variance structure using the packages "nlm" and "predictmeans" in R version 3.1 [37]. The effect of DNA extraction kit and the $\mathrm{CO}_{2}$ on the DNA yield (ng DNA/g dry soil) and 
quality (A260/A280 ratio) were tested using the data from individual soil cores. The effect of elevated atmospheric $\mathrm{CO}_{2}$, and sampling protocol on bacterial $16 \mathrm{~S}$ rRNA gene abundance were conducted separately for the two DNA extraction kits. The mixed effects model used had the $\mathrm{CO}_{2}$ ring nested within block as a random effect while atmospheric $\mathrm{CO}_{2}$ concentration, sampling protocol and their interaction were considered as fixed effects. Mean separation was performed using Fisher's LSD test.

\section{Results}

\subsection{The Effect of Different Sampling Extraction Kits on DNA Yield under Elevated $\mathrm{CO}_{2}$}

The DNA yield from the MoBio kit was significantly lower than that from the Fast kit $(\mathrm{P}<0.001)$ (Figure $2(\mathrm{~A})$ ). The DNA yield from both kits was significantly lower in the $\mathrm{eCO}_{2}$ soil and the percentage reduction was similar (22\% for MoBio and 25\% for Fast kit) (Figure 2(A)). The DNA extracted from $\mathrm{aCO}_{2}$ and $\mathrm{eCO}_{2}$ soils was of the same quality $\left(\mathrm{CO}_{2} \mathrm{P}=0.357\right)$ but the MoBio kit extracted significantly $(\mathrm{P}<0.001)$ higher quality DNA than the Fast kit irrespective of the $\mathrm{CO}_{2}$ treatment (Figure 2(B)).

\subsection{The Effect of Different Extraction Kits on Bacterial Abundance under Elevated $\mathrm{CO}_{2}$}

Comparing the values between Figure 3(A) and Figure 3(B) (note the different scales) shows bacterial abundance measured as $16 \mathrm{~S}$ rRNA copy number was much lower measured from the DNA extracted from the MoBio kit compared to the DNA from the Fast kit. There was no significant effect $(\mathrm{P}=0.722)$ of the experimental protocol on bacterial abundance measured from the DNA of the MoBio kit (Figure 3(A)); by contrast, a significant difference between the sam-
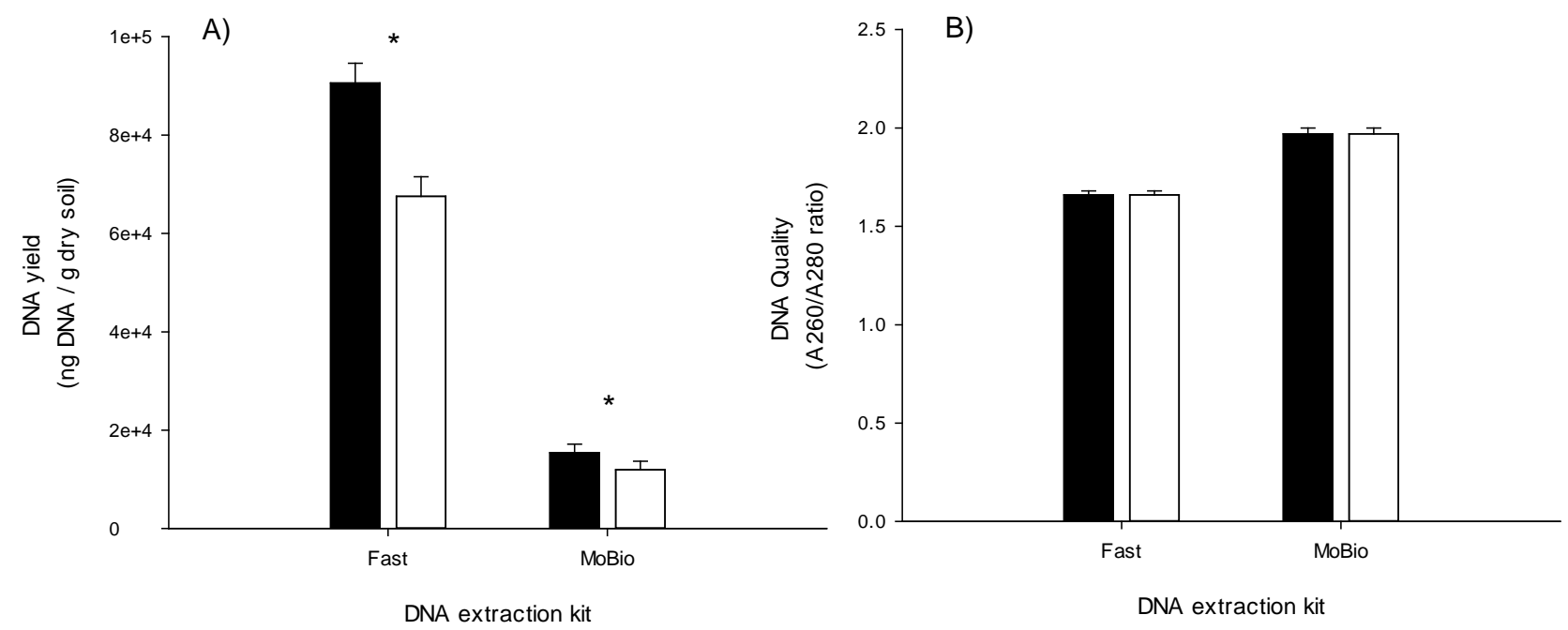

Figure 2. The (A) yield and (B) quality of DNA extracted from soil samples taken under Agrostis capillaris plants growing under ambient (filled bars) or elevated (open bars) atmospheric $\mathrm{CO}_{2}$ using two DNA extraction kits and soil sampling method (A) from Figure 1. * denotes significant difference between $\mathrm{CO}_{2}$ treatments using Fisher's LSD test at the $\mathrm{P} \leq 0.05$ level. 


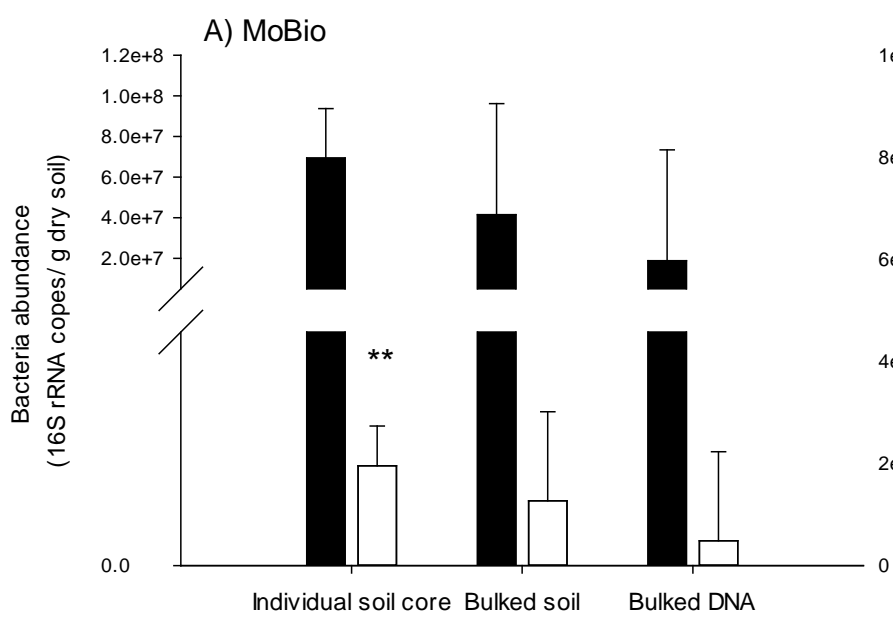

Sampling protocol

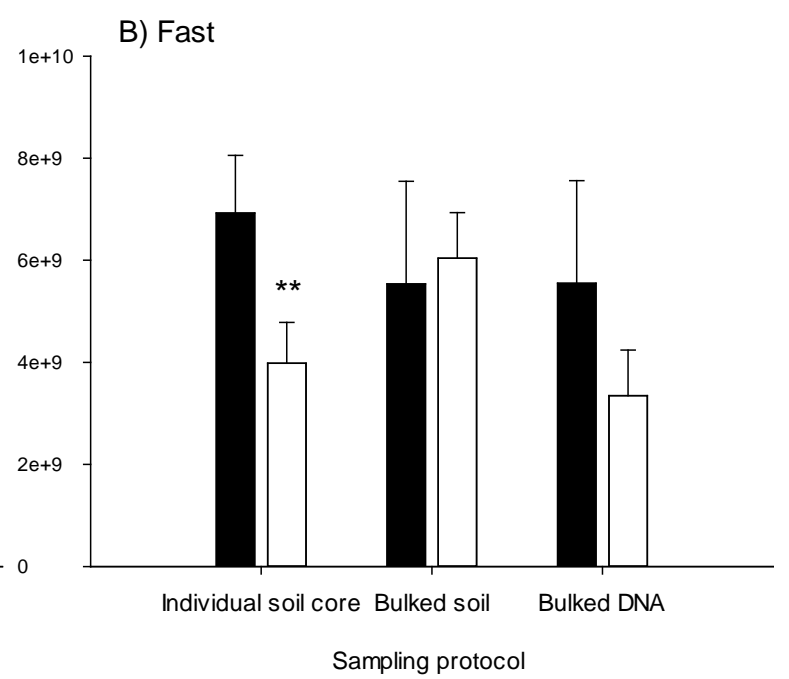

Sampling protocol

Figure 3. The abundance of bacteria in soil sampled under plants growing at ambient (closed bar) or elevated (open bars) atmospheric $\mathrm{CO}_{2}$ measured as copy numbers of the $16 \mathrm{~S}$ rRNA gene and identified using three experimental protocols and two DNA extraction kits: (A) MoBio kit, (B) Fast kit. ${ }^{*}$ denotes significant difference between $\mathrm{CO}_{2}$ treatments using Fisher's LSD test at the $\mathrm{P} \leq 0.01$ level.

pling method was evident when using the Fast kit $(\mathrm{P}<0.001)$ (Figure $3(\mathrm{~B})$ ). The DNA from both kits showed soil bacterial abundance at $\mathrm{eCO}_{2}$ was marginally lower $\left(\mathrm{P}=0.100 \mathrm{MoBio}\right.$ and 0.084 Fast) compared to $\mathrm{aCO}_{2}$. However, only the individual soil core method was able to detect this difference at a significant level as calculated using Fisher's LSD at the $\mathrm{P} \leq 0.01$ level (Figure 3 ).

\section{Discussion}

\subsection{Effect of Different Methods of Soil Sampling and DNA Extraction on the Identification of Quantity and Quality under Elevated $\mathrm{CO}_{2}$}

The DNA extraction rates convert to about $7 \mu \mathrm{g}$ DNA g dry soil-1 for the Fast kit and $2 \mu \mathrm{g}$ DNA g dry soil-1 for the MoBio kit. These values are higher than those reported byJossi et al. (2006) [16] in another grassland under elevated $\mathrm{CO}_{2}$ where the average values for two perennial grasses were 6.0 and $8.1 \mu \mathrm{g}$ DNA g fresh soil-1. The amount of DNA extracted was significantly greater using the Fast kit and this kit extracted a significantly greater amount from the $\mathrm{aCO}_{2}$ compared to the $\mathrm{eCO}_{2}$ soil. The greater amount of DNA extracted by the Fast kit is consistent with much higher 16s rRNA gene copy numbers using this kit. Similar to our studyVishnivetskaya et al (2014) [38] extracted more DNA using the Fast kit than the MoBio kit from permafrost soils in the Arctic; although in their study both the Fast and MoBio kits extracted high quality DNA (see Table 1 of Vishnivetskaya et al (2014) for comparison of the kits) [38]. The DNA extracted by the MoBio kit in our study was of a higher quality than that extracted using the Fast kit. The quantity and quality of the soil DNA extracted are important for downstream techniques to analyse microbial community structure [39]. Feinstein et al (2009) found that incomplete DNA extraction from soil resulted 
in biased estimates of ribosomal copy number and bacterial community composition [40]. The quality of DNA characterised by A260/280 ratio is important as it indicates co-extraction of impurities such as humic substances with DNA that can inhibit the activity of polymerase chain reaction [41].

\subsection{Effect of Different Methods of Soil Sampling and DNA Extraction on the Bacterial Abundance and Cost of the $16 \mathrm{~S}$ rRNA Gene under Elevated $\mathrm{CO}_{2}$}

We found that bacterial abundance measured as copy number of the 16S rRNA gene and showing whether the result was significant or non-significant was more impacted by the soil sampling approach than the DNA extraction kit (Table 1). The soil sampling approach most widely used in $\mathrm{CO}_{2}$ studies is the bulked soil method providing a single soil sample per FACE ring or OTC; examples where bacterial abundance has been measured are given in Table 1 and there are further examples where the object was to study bacterial community structure and diversity [42] [16]. The results for bacterial abundance in $\mathrm{eCO}_{2}$ field experiments shows a consistent reduction in abundance with $\mathrm{eCO}_{2}$; the only exception in the experiments listed being a slight and non-significant response in one set of measurements in this paper (Figure 3(B)). However, despite the consistent response across experiments there were only three examples where the bacterial abundance was significantly different between $\mathrm{aCO}_{2}$ and $\mathrm{eCO}_{2}$ and this was when individual soil cores were studies rather than a bulked sample (Table 1).

Using the individual core method meant that in our case 30 samples were required to be analysed compared to 6 for the bulk sampled method. The approximate total cost for single gene abundance (DNA extraction and qPCR) for 30 samples was 5 fold higher than for 6 bulked samples but similar for the two kits. There was also 3 fold increase in technical time required for the individual soil core approach compared to the bulked soil sample approach. Although the cost of analysis of individual soil core approach can be reduced by 1.5 fold by extracting DNA from individual cores and then bulking the DNA for qPCR (method C) in Figure 1) the statistical analysis indicated that this method resulted in high variability and ultimately a non-significant difference between treatments although the same trend was observed as with individual soil core method.

\section{Conclusions}

Three different sampling methods and two different DNA extraction kits tested. The first because microbes are distributed heterogeneously in soil so the sampling procedure might be expected to influence the accuracy and precision of the population estimate and the second because the quantity and quality of DNA extracted influences the microbial analyses that can be performed and can introduce bias. We found that bacterial abundance was consistently lower under $\mathrm{eCO}_{2}$ but we were only able to establish a statistical difference where a more intense sampling regime was used and bulking of the soil sample was avoided. A 
reduction in bacterial abundance is a consistent outcome in $\mathrm{eCO}_{2}$ field experiments but the only other occasion where this reduction has been found to be significant was also where individual soil cores were analysed rather than the samples being bulked. We conclude that while there is extra work and cost attached to more detailed sampling this approach is highly desirable if we are to make robust conclusions about the impacts of $\mathrm{eCO}_{2}$ on soil microbes.

Our study demonstrated that increasing number of replicates per $\mathrm{CO}_{2}$ treatment improves the precision of microbial population estimates and that the extra effort and cost is likely to be a justifiable investment. This aspect of experimentation has not received attention in $\mathrm{CO}_{2}$ experiments in the past and our results highlights that the choice of soil sampling protocol and DNA extraction method needs to be considered carefully if microbial responses to $\mathrm{eCO}_{2}$ are to be characterised accurately.

\section{Acknowledgements}

Research costs were provided by AgResearch. The China Scholarship Council provided a Research Fellowship to Fengxia Li. The authors are grateful to Phil Theobald and Shona Brock for technical assistance.

\section{References}

[1] De Graaff, M.-A., Van Groenigen, K.-J., Six, J., Hungate, B. and Van Kessel, C. (2006) Interactions between Plant Growth and Soil Nutrient Cycling under Elevated $\mathrm{CO}_{2}$ : A Meta-Analysis. Global Change Biology, 12, 2077-2091. https://doi.org/10.1111/j.1365-2486.2006.01240.x

[2] Ross, D.J., Newton, P.C.D., Tate, K.R. and Luo, D. (2013) Impact of a Low Level of $\mathrm{CO}_{2}$ Enrichment on Soil Carbon and Nitrogen Pools and Mineralization Rates over Ten Years in a Seasonally Dry, Grazed Pasture. Soil Biology and Biochemistry, 58, 265-274. https://doi.org/10.1016/j.soilbio.2012.12.011

[3] Sillen, W.M.A. and Dieleman, W.I.J. (2012) Effects of Elevated $\mathrm{CO}_{2}$ and N Fertilization on Plant and Soil Carbon Pools of Managed Grasslands: A Meta-Analysis. Biogeosciences, 9, 2247-2258.

[4] Bloom, J.A., Burger, M., Kimball, B.A. and Pinter Jr., P. (2014) Nitrate Assimilation Is Inhibited by Elevated $\mathrm{CO}_{2}$ in Field-Grown Wheat. Nature Climate Change, 4 , 477-480. https://doi.org/10.1038/nclimate2183

[5] Gentile, R., Dodd, M., Lieffering, M., Brock, S.C., Theobald, P.W. and Newton, P.C.D. (2012) Effects of Long-Term Exposure to Enriched $\mathrm{CO}_{2}$ on the $\mathrm{Nu}$ trient-Supplying Capacity of a Grassland Soil. Biology and Fertility of Soils, 48, 357-362. https://doi.org/10.1007/s00374-011-0616-7

[6] Myers, S.S., et al. (2014) Increasing $\mathrm{CO}_{2}$ Threatens Human Nutrition. Nature, 510, 139-142. https://doi.org/10.1038/nature13179

[7] Reich, P.B. (2009) Elevated $\mathrm{CO}_{2}$ Reduces Losses of Plant Diversity Caused by nitrogen Deposition. Science, 326, 1399-1402. https://doi.org/10.1126/science.1178820

[8] Hungate, B.A., et al. (2009) Assessing the Effect of Elevated Carbon Dioxide on Soil Carbon: A Comparison of Four Meta-Analyses. Global Change Biology, 15, 2020-2034. https://doi.org/10.1111/j.1365-2486.2009.01866.x 
[9] Schimel, J.P. and Bennett, J. (2004) Nitrogen Mineralization: Challenges of a Changing Paradigm. Ecology, 85, 591-602.

[10] Van Der Heijden, M.G.A., Bardgett, R.D. and Van Straalen, N.M. (2008) The Unseen Majority: Soil Microbes as Drivers of Plant Diversity and Productivity in Terrestrial Ecosystems. Ecology Letters, 11, 296-310. https://doi.org/10.1111/j.1461-0248.2007.01139.x

[11] Bowatte, S., Newton, P.C.D., Hill, A.M., Theobald, P., Luo, D., Hovenden, M. and Osanai, Y. (2013) Offspring of Plants Exposed to Elevated or Ambient $\mathrm{CO}_{2}$ Differ in Their Impacts on Soil Nitrification in a Common Garden Experiment. Soil Biology and Biochemistry, 62, 134-136.

[12] Díaz, S., Grime, J.P., Harris, J. and McPherson, E. (1993) Evidence of a Feedback Mechanism Limiting Plant Response to Elevated Carbon Dioxide. Nature, 364, 616-617. https://doi.org/10.1038/364616a0

[13] Hu, S., Tu, C., Chen, X. and Gruver, J.B. (2006) Progressive N Limitation of Plant Response to Elevated $\mathrm{CO}_{2}$ : A Microbiological Perspective. Plant and Soil, 289, 47-58. https://doi.org/10.1007/s11104-006-9093-4

[14] Singh, B.K., Bardgett, R.D., Smith, P. and Reay, D.S. (2010) Microorganisms and Climate Change: Terrestrial Feedbacks and Mitigation Options. Nature Reviews Microbiology, 8, 779-790. https://doi.org/10.1038/nrmicro2439

[15] Zak, D.R., Pregitzer, K.S., King, J.S. and Holmes, W.E. (2000) Elevated Atmospheric $\mathrm{CO}_{2}$, Fine Roots and the Response of Soil Microorganisms: A Review and Hypothesis. New Phytologist, 147, 201-222. https://doi.org/10.1046/j.1469-8137.2000.00687.x

[16] Jossi, M., Fromin, N., Tarnawski, S., Kohler, F., Gillet, F., Aragno, M. and Hamelin, J. (2006) How Elevated pCO2 Modifies Total and Metabolically Active Bacterial Communities in the Rhizosphere of Two Perennial Grasses Grown under Field Conditions. FEMS Microbiology Ecology, 55, 339-350. https://doi.org/10.1111/j.1574-6941.2005.00040.x

[17] Baker, K.L., Langenheder, S., Nicol, G.W., Ricketts, D., Killham, K., Campbell, C.D. and Prosser, J.I. (2009) Environmental and Spatial Characterisation of Bacterial Community Composition in Soil to Inform Sampling Strategies. Soil Biology and Biochemistry, 41, 2292-2298.

[18] Kirk, J.L., Beaudette, L.A., Hart, M., Moutoglis, P., Klironomos, J.N., Lee, H. and Trevors, J.T. (2004) Methods of Studying Soil Microbial Diversity. Journal of Microbiological Methods, 58, 169-188.

[19] Lombard, N., Prestat, E., van Elsas, J.D. and Simonet, P. (2011) Soil-Specific Limitations for Access and Analysis of Soil Microbial Communities by Metagenomics. FEMS Microbiology Ecology, 78, 31-49. https://doi.org/10.1111/j.1574-6941.2011.01140.x

[20] Carrigg, C., Rice, O., Kavanagh, S., Collins, G. and O’Flaherty, V. (2007) DNA Extraction Method Affects Microbial Community Profiles from Soils and Sediment. Applied Microbiology and Biotechnology, 77, 955-964. https://doi.org/10.1007/s00253-007-1219-y

[21] Leite, D.C.A., Balieiro, F.C., Pires, C.A., Madari, B.E., Rosado, A.S., Coutinho, H.L.C. and Peixoto, R.S. (2014) Comparison of DNA Extraction Protocols for Microbial Communities from Soil Treated with Biochar. Brazilian Journal of Microbiology, 45, 175-183. https://doi.org/10.1590/S1517-83822014000100023

[22] Newton, P.C.D., Allard, V., Carran, R.A. and Lieffering, M. (2006) Impacts of Elevated $\mathrm{CO}_{2}$ on a Grassland Grazed by Sheep: The New Zealand FACE Experiment. 
In: Nosberger, J., Long, S.P., Norby, R.J., Stitt, M., Hendrey, G.R. and Blum, H., Eds., Managed Ecosystems and CO2: Case Studies, Processes, and Perspectives. Ecological Studies: Analysis and Synthesis, Vol. 187, Springer-Verlag, Berlin, 157-171. https://doi.org/10.1007/3-540-31237-4_9

[23] Castro, H.F., Classen, A.T., Austin, E.E., Norby, R.J. and Schadt, C.W. (2010) Soil Microbial Community Responses to Multiple Experimental Climate Change Drivers. Applied and Environmental Microbiology, 76, 999-1007. https://doi.org/10.1128/AEM.02874-09

[24] Dunbar, J., Gallegos-Graves, L.V., Steven, B., Mueller, R., Hesse, C., Zak, D.R. and Kuske, C.R. (2014) Surface Soil Fungal and Bacterial Communities in Aspen Stands Are Resilient to Eleven Years of Elevated $\mathrm{CO}_{2}$ and $\mathrm{O}_{3}$. Soil Biology and Biochemistry, 76, 227-234.

[25] Haugwitz, M., Bergmark, L., Priemé, A., Christensen, S., Beier, C. and Michelsen, A. (2014) Soil Microorganisms Respond to Five Years of Climate Change Manipulations and Elevated Atmospheric $\mathrm{CO}_{2}$ in a Temperate Heath Ecosystem. Plant and Soil, 374, 211-222. https://doi.org/10.1007/s11104-013-1855-1

[26] Hayden, H.L., et al. (2012) Changes in the Microbial Community Structure of Bacteria, Archaea and Fungi in Response to Elevated $\mathrm{CO}_{2}$ and Warming in an Australian Native Grassland Soil. Environmental Microbiology, 14, 3081-3096. https://doi.org/10.1111/j.1462-2920.2012.02855.x

[27] Oppermann, B.I., et al. (2010) Soil Microbial Community Changes as a Result of Long-Term Exposure to a Natural $\mathrm{CO}_{2}$ Vent. Geochimica et Cosmochimica Acta, 74, 2697-2716.

[28] Newton, P.C.D., et al. (2014) Selective Grazing Modifies Previously Anticipated Responses of Plant Community Composition to Elevated $\mathrm{CO}_{2}$ in Temperate Grassland. Global Change Biology, 20, 158-169. https://doi.org/10.1111/gcb.12301

[29] Edwards, G., Clark, H. and Newton, P.C.D. (2001) The Effects of Elevated $\mathrm{CO}_{2}$ on Seed Production and Seedling Recruitment in a Sheep-Grazed Pasture. Oecologia, 127, 383-394. https://doi.org/10.1007/s004420000602

[30] Harris, W. and Brougham, R.W. (1968) Some Factors Affecting Change in Botanical Composition in a Ryegrass-White Clover Pasture under Continuous Grazing. New Zealand Journal of Agricultural Research, 11, 15-38. https://doi.org/10.1080/00288233.1968.10431631

[31] Allard, V., Newton, P.C.D., Lieffering, M., Clark, H., Matthew, C., Soussana, J.F. and Gray, Y.S. (2003) Nitrogen Cycling in Grazed Pastures at Elevated $\mathrm{CO}_{2}: \mathrm{N} \mathrm{Re}-$ turns by Ruminants. Global Change Biology, 9, 1731-1742.

https://doi.org/10.1111/j.1365-2486.2003.00711.x

[32] Cornforth, I.S. and Sinclair, A.G. (1984) Fertiliser and Lime Recommendations for Pastures and Crops in New Zealand. 2nd Revised Edition, Ministry of Agriculture and Fisheries, Wellington.

[33] Pirondini, A., Bonas, U., Maestri, E., Visioli, G., Marmiroli, M. and Marmiroli, N. (2010) Yield and Amplificability of Different DNA Extraction Procedures for Traceability in the Dairy Food Chain. Food Control, 21, 663-668.

[34] Quigley, L., O’Sullivan, O., Beresford, T.P., Paul Ross, R., Fitzgerald, G.F. and Cotter, P.D. (2012) A Comparison of Methods Used to Extract Bacterial DNA from Raw Milk and Raw Milk Cheese. Journal of Applied Microbiology, 113, 96-105. https://doi.org/10.1111/j.1365-2672.2012.05294.x

[35] Heuer, H., Krsek, M., Baker, P., Smalla, K. and Wellington, E.M.H. (1997) Analysis of Actinomycete Communities by Specific Amplification of Genes Encoding 16S 
rRNA and Gel-Electrophoretic Separation in Denaturing Gradients. Applied and Environmental Microbiology, 63, 3233-3241.

[36] Yates, M.D., et al. (2012) Convergent Development of Anodic Bacterial Communities in Microbial Fuel Cells. ISME Journal, 6, 2002-2013.

https://doi.org/10.1038/ismej.2012.42

[37] Pinheiro, J., Bates, D., DebRoy, S. and Sarkar, D. (2013) nlme: Linear and Nonlinear Mixed Effects Models. R Package Version 3.1-109. R Foundation for Statistical Computing.

[38] Vishnivetskaya, T.A., et al. (2014) Commercial DNA Extraction Kits Impact Observed Microbial Community Composition in Permafrost Samples. FEMS Microbiology Ecology, 87, 217-230. https://doi.org/10.1111/1574-6941.12219

[39] Hazen, T.C., Rocha, A.M. and Techtmann, S.M. (2013) Advances in Monitoring Environmental Microbes. Current Opinion in Biotechnology, 24, 526-533.

[40] Feinstein, L.M., Woo, J.S. and Blackwood, C.B. (2009) Assessment of Bias Associated with Incomplete Extraction of Microbial DNA from Soil. Applied and Environmental Microbiology, 75, 5428-5433. https://doi.org/10.1128/AEM.00120-09

[41] Fortin, N., Beaumier, D., Lee, K. and Greer, C.W. (2004) Soil Washing Improves the Recovery of Total Community DNA from Polluted and High Organic Content Sediments. Journal of Microbiological Methods, 56, 181-191.

[42] Ge, Y., Chen, C., Xu, Z., Oren, R. and He, J.Z. (2010) The Spatial Factor, Rather than Elevated $\mathrm{CO}_{2}$, Controls the Soil Bacterial Community in a Temperate Forest Ecosystem. Applied and Environmental Microbiology, 76, 7429-7436.

https://doi.org/10.1128/AEM.00831-10

Submit or recommend next manuscript to OALib Journal and we will provide best service for you:

- Publication frequency: Monthly

- 9 subject areas of science, technology and medicine

- Fair and rigorous peer-review system

- Fast publication process

- Article promotion in various social networking sites (LinkedIn, Facebook, Twitter, etc.)

- Maximum dissemination of your research work

Submit Your Paper Online: Click Here to Submit

Or Contact service@oalib.com 